\title{
An Empirical Study on the Influence of Internal and External Effects of Human Capital on Business Performance
}

\author{
Wenjie Yang ${ }^{1}$, Shun-Ho $\mathrm{Chu}^{2,}{ }^{*}$, Zhe Liu ${ }^{2}$ \\ ${ }^{1}$ School of Business, Lingnan Normal University, Zhanjiang, China \\ ${ }^{2}$ School of Business, Macau University of Science and Technology, Macau, China \\ Email address: \\ 842841395@qq.com (Wenjie Yang), shchu@must.edu.mo (Shun-Ho Chu),371903458@qq.com (Zhe Liu) \\ ${ }^{*}$ Corresponding author
}

\section{To cite this article:}

Wenjie Yang, Shun-Ho Chu, Zhe Liu. An Empirical Study on the Influence of Internal and External Effects of Human Capital on Business Performance. Journal of Business and Economic Development. Vol. 4, No. 3, 2019, pp. 74-80. doi: 10.11648/j.jbed.20190403.11

Received: June 12, 2019; Accepted: July 10, 2019; Published: July 23, 2019

\begin{abstract}
Human resources is one of the important driving forces for the company's business performance growth; therefore, this has caused companies to pay attention to the concept of human capital and human resource management of human capital structure. For a company, the value of the company does not come entirely from physical assets, but also from intangible assets; therefore, the education and skills of employees are critical. This study selects annual data of China's 33 listed energy companies from 2012 to 2017, and uses revenue capacity and return on investment in human capital as the dependent variable, employee's education years, educational Gini index, average employees' compensation, average top managements' compensation and ratio of skillful employees to total employees as the independent variables, to employ panel data methods to empirically study the impact of human capital on business performance from the perspective of internal and external effects. The empirical results show that the employee's education years and educational Gini index in the company's internal effects have a positive impact on business performance. On the other hand the average employees' compensation and average top managements' compensation in the company's in the company's external effects have a positive impact on business performance. The conclusion of this study: is that human capital of Chinese listed energy companies plays an important role in business performance.
\end{abstract}

Keywords: Human Capital, Business Performance, Educational Gini Index

\section{Introduction}

In recent years, with the continuous advancement of networks and technologies, the business model has developed rapidly, and the degree of globalization and market competition have become increasingly high. Enterprises paying attention to human capital as a key factor in improving the organization and operation ability of enterprises can improve the work efficiency of employees and the sustainable competitive advantage of enterprises. Therefore, human capital has surpassed physical assets as the most effective link to innovation, competitiveness and economic growth. For the enterprise, the education and skills of the employees are crucial; because the enterprise value is not all derived from the material assets, but also can be generated from the intangible assets.
However, scholars' research focuses on knowledgeintensive industries such as information technology and integrated circuits, but little empirical research on traditional energy industry. In order to fill this research gap, this study attempts to empirically study the impact of human capital structure on business performance through the panel data analysis model from the perspective of internal and external effects. Referring to the empirical results, this study will provide some suggestions for the traditional energy industry.

\section{Research Theory}

\subsection{Human Capital Theory}

Scholars have differently elaborated on the connotation of human capital. Becker [1] defines human capital as the 
knowledge, skills, and abilities that individuals already possess. Becker [2] argues that the level of human capital in a business organization is based on the natural ability of employees to receive formal education and from work practices, consisting of intelligence and education. Coleman [3] argues that human capital is an individual's knowledge and ability to improve behavior and promote economic growth, and that this type of human capital, knowledge and ability, can be obtained in a variety of ways. Schultz [4] argues that the origin of human capital theory and the macroeconomic field. Human capital is interpreted as an important factor in improving employee capital, improving labor productivity, optimizing the company's capital structure, and maintaining the company's continued competitiveness.

Scholars further distinguish and explain the connotation of human capital. Brooking [5] proposed that human capital can be divided into six categories: personality traits, education level, job-related knowledge, job-related skills, work-related licenses and qualifications, work potential; the company's internal employee capital is the most dynamic and creativity of human capital. Pennings, Lee, Witteloostuijn [6] construct the human capital model that can be widely applied to the company and industry human capital as a personal trait includes employee education level, training skills, industry knowledge, general management skills and entrepreneurial experience. Namasivayam, Denizci [7] believes that human capital covers knowledge, education, skills, and psychometric assessments. The capital value of the organization includes employee education, employee ability, organizational culture, a collection of all traits, and ultimately create more added value to the organization.

\subsection{Human Capital Measurement}

Dzinkowski [8] points out the measurement of human capital in smart capital, the reputation of the company's employees, employee satisfaction, the proportion of new employees with less than two years of service, employee creativity and adoption rate, annual salary of employees, and The average value created and the return on employee compensation are used as a measure. Becker, Husield, Ulrich [9] based on efficiency and investment, proposes how to measure the human capital approach in human resource management. Hillma, Dalziel [10] point out that corporate directors and senior management are highly concentrated in the company's knowledge, technology and capabilities, and are an important manifestation of corporate intellectual capital. In addition, some scholars have proposed a set of three methods of human capital measurement based on cost, income and education; first, based on the cost perspective, the human capital investment of the production process, including the cost of raising and educating personnel; secondly, Based on the income perspective, the total discounted value of all future incomes of all individuals in the enterprise is used to measure the human capital stock and the economic value that human capital can generate; finally, based on the educational perspective In the way of learning and education, enterprises specialize in labor through human capital investment.

In summary, there are many measures for human capital, but most of then have limitations. The reason is that there are imbalances in the measurement standards, such as the data are difficult to accurately estimate, and the deviation from the true value of human capital will be unavoidable. This paper uses the education salary investment method from the relevant data of listed energy companies to measure human capital from internal and external effects.

\subsection{Human Capital Measurement Based on Internal Effect Perspective}

The internal effect of enterprise human capital is mainly reflected in the fact that employees themselves have the level of school education, rather than the level of knowledge and ability after receiving enterprise training, that is, the initial stock of human capital brought to the company by employees as individuals. The initial stock of human capital will be measured by two factors: the number of years of employee education, and the Education Gini index.

\subsection{Human Capital Measurement Method Based on External Effect Perspective}

The external effects of corporate human capital are mainly reflected in pre-job training, professional skills training, and salary and salaries. The professional skills and labor productivity of all employees of the enterprise, and the human capital gains that bring economic effects to the enterprise. All employees of the company can be divided into directors, supervisors and senior management (referred to as top managements) and ordinary employees. Therefore, the external effects of corporate human capital will be measured by four factors: the average salary of employees, the average training expenses of employees, the high average salary of directors, and the ratio of technical employees to total employees.

\section{Methodology}

\subsection{Data}

This paper uses data from the Shanghai Stock Exchange, Shenzhen Stock Exchange and Guotaian Database (CSMAR). Annual data covering 33 Chinese used energy companies are over the period from 2012 to 2017.

\subsection{Research Hypothesis}

\subsubsection{Hypothesis Based on the Internal Effect of Human Capital}

(1) Employee's education years

Education can cultivate knowledge and skills, increase productivity, and help improve business performance. Teixeira, Queiros [11] use panel data from 21 OECD and 9 countries to use the average age of education for adults as an independent variable, to explore the impact of economic 
growth, human capital and institutional reforms. The results show that the higher the adult education period, the faster the country's economic growth, and the human capital stock has a positive positive impact on economic growth.

Hypothesis 1: Employee's education years have a positive impact on business performance.

(2) Educational Gini index

The Gini coefficient is a measure that can analyze the degree of dispersion of all variables and determine the degree of distribution difference. Maas, Criel [12] use the primary school admission data of 16 countries in East Africa to estimate the distribution of educational level, the results show that the average enrollment rate and education inequality have a negative impact. This study selects the educationl Gini coefficient to measure the distribution of education within a certain range. The value is between 0 and 1. When the educational Gini coefficient approaches 0 , indicating that the educational level distribution is more equal within the specific range. When the Gini coefficient of education is larger and approaches 1 , it indicates that the degree of education is unevenly distributed within the specific range. In the company's human capital structure, the number of employees with college education increases, the number of employees in education increases, the degree of education distribution tends to be unequal, and the Gini coefficient of education will approach 1 . Therefore, this study believes that the employee education Gini coefficient has a positive impact on business performance.

Hypothesis 2: Educational Gini index has a positive impact on business performance.

\subsubsection{Hypothesis Based on the External Effect of Human Capital}

(1) Average employees' compensation

The company's employees can be divided into two categories, one refers to directors, supervisors and senior management; the other refers to ordinary employees. In order to further measure what kind of employees contribute more to the company's business performance, it is divided into two categories to measure employee income. Ballot, Fakhfakh, Taymaz [13] use panels data from France and Sweden companies to explore the relationship of the human capital, R\&D costs and corporate performance of French and Swedish companies with employee compensation, employee training funds, and staff training time. The results of the study show that employee compensation, training funds and time in the French companies are significant for corporate capital appreciation. Therefore, this study believes that the average salary of employees has a positive impact on business performance.

Hypothesis 3: Average employees' compensation has a positive impact on business performance.

(2) Average top managements' compensation

The top managements' compensation accounts for a large proportion of the total remuneration of employees in the energy industry. The education level of top managements personnel is generally higher than that of the overall employees. Therefore, the return on human capital investment of top managements cannot be ignored. Peng, Suyin and Long [14] based on CSMAR database China's 247 GEM annual report collection panel data, exploring the influence of top management human capital and ordinary employees' human capital on the company's business performance.

Hypothesis 4: Average top managements' compensation has a positive impact on business performance.

(3) Ratio of skillful employees to total employees

Skillful employees can reduce production cost, improve production processes, and help improve business performance. Fedyk, Hodson [15] employ the employment information of listed companies in the United States, and use the regression of the variables such as the percentage of technicians as a percentage of the total number of people, to explore the interaction between human capital and corporate performance of US listed companies. Research results show that among the listed companies in the United States, the company's human capital has a positive impact on the business performance. Also, this study believes that the proportion of technical employees has a positive impact on the business performance.

Hypothesis 5: Ratio of skillful employees to total employees has a positive impact on the business performance.

\subsection{Research Variables}

\subsubsection{Dependent Variables}

\section{(1) Revenue capacity (RC)}

The amount of revenue by each employee can create for the company. The operating income is the value of the company's operating performance. The higher the operating income, the stronger the company's operating ability and the higher the company's operating performance. The calculation formula is expressed as follows:

$$
\mathrm{RC}=\mathrm{Ln}\left(\frac{\text { total operating income }}{\text { total number of employees }}\right)
$$

whereas, the total operating income is taken from the financial statements of listed companies to measure the operating income generated by listed energy companies through the provision of labor services and commodity sales the logarithm of total operating income scaled by the total number of employees is used to measure the per capita revenue of employees who are inflows of economic benefits to the company.

(2) Return on investment in human capital (ROIHC)

We measure the economic profit and return that can be brought about by investing one yuan of human capital per investment. The economic income is the operating income minus the human capital expenditure. The calculation formula is expressed as follows:

$$
\text { ROIHC }=\frac{\text { operating income }-[\text { operating expenses }-(\text { salary cost }+ \text { welfare cost })]}{\text { salary cost }+ \text { welfare cost }}
$$


whereas, the income is measured by the net operating income, Both the salary cost and the welfare cost are taken from the public annual report of the listed energy companies, in order to calculate the return on human capital investment of the listed energy company.

\subsubsection{Independent Variables}

(1) Employee's education years (EDUAV)

The total years of employees education is measured by the weighted average of the education time of total number of employees. According to the educational system standard, the accumulated school education years are calculated: 19 years for master and Ph.D., 16 years for undergraduate students, 15 years for junior colleges, and 12 years for secondary technical schools and below. The formula for calculating the number of years of employee education is as follows:

$$
\text { EDUAV }=\frac{\text { total years of employees education }}{\text { total number of employees }}
$$

Among them, the formula for calculating the total number of years of education for employees is as follows:

Total number of years of education for employees = number of masters and Ph.D.* $19+$ number of undergraduates $* 16+$ number of junior colleges $* 15+$ secondary technical school and the following number $* 12$

(2) Educational Gini index (EGC)

The educational Gini index can measure the distribution of human capital. The calculation formula is expressed as follows:

$$
\mathrm{EGC}=\left(\frac{1}{2 \mathrm{H}}\right) \sum_{\mathrm{i}=0}^{\mathrm{n}} \cdot \sum_{\mathrm{j}=0}^{\mathrm{n}}\left|\mathrm{X}_{\mathrm{i}}-\mathrm{X}_{\mathrm{j}}\right| \mathrm{n}_{\mathrm{i}} \mathrm{n}_{\mathrm{j}}
$$

Among them, $\mathrm{H}$ is the average accumulated school education years of the employed population, based on the education system standard, not going to school for 0 years, primary school for 6 years, junior high school for 3 years, high school for 3 years, secondary school for 3 years, junior college for 3 years, undergraduate 4 years, master's degree is 3 years, that is, the accumulated school education years are 0 years for not attending school, 6 years for elementary school, 9 years for junior high school, 12 years for high school, 12 years for secondary school, 15 years for junior college, 16 for undergraduate. The year and master's degree are 19 years.

$\mathrm{X}_{\mathrm{i}}=$ The number of years of accumulated school education in the school education qualification $\mathrm{i}$ of the employed population;

$\mathrm{X}_{\mathrm{j}}=$ The number of years of accumulated school education in the school education qualification $\mathrm{j}$ of the employed population;

$\mathrm{N}_{\mathrm{i}}=$ the proportion of employed people in the school education stage $i$ to the total employed population;

$\mathrm{N}_{\mathrm{j}}=$ The proportion of employed people in the school education stage $\mathrm{j}$ to the total employed population.

Educational Gini index is between 0 and 1. If the educational Gini coefficient is close to 1 , it means that the employment population is concentrated in an education stage, showing the imbalance of human capital.

(3) Average employees' compensation (AS)

The average employee compensation is measured the logarithm of by the total employee compensation to the total number of employees. The calculation formula is expressed as follows:

$$
\mathrm{AS}=\operatorname{Ln}\left(\frac{\text { total compensation }}{\text { tatal number of employees }}\right)
$$

(4) Average top managements' compensation (CHIEF)

The Average top managements' compensation is measured by the logarithm of the total remuneration of directors, supervisors and senior management to the number of directors, supervisors and senior management. The calculation formula is expressed as follows:

$$
\text { CHIEF }=\operatorname{Ln}\left(\frac{\text { managements' }{ }^{\prime} \text { mpensation }}{\text { number of top managements }}\right)
$$

(5) Ratio of skillful employees to total employees (TECH) Ratio of skillful employees to total employees disclosed the level of skills owned by employees in the company. The calculation formula is expressed as follows:

$$
\mathrm{TECH}=\frac{\text { number of skillful employees }}{\text { total employees }}
$$

\subsubsection{Control Variables}

(1) growth rate of operating income (GROWTH)

The growth rate of operating income refers to the difference between the current operating income and the previous operating income, except for the ratio of operating income in the previous period. The calculation formula is expressed as follows:

$$
\text { GROWTH }=\left(\frac{\text { main business income in the current period-main business income in the previous period }}{\text { main business income in the previous period }}\right)
$$

(2) Ratio of liabilities to assets (DA)

The ratio of liabilities to assets refers to the ratio of the total liabilities of the company scaled by the total assets. The calculation formula is expressed as follows:

$$
\mathrm{DA}=\frac{\text { total libilities }}{\text { total assets }}
$$

(3) Enterprise size (SIZE)

Enterprise size refers to the natural logarithm of the company's total assets. The calculation formula is expressed as follows:

$$
\text { SIZE }=\operatorname{Ln}(\text { total assets })
$$

\subsection{Research Models}

3.4.1. Using Revenue Capacity ( $R C$ ) as Dependent Variable

(1) model 1-1 using EDVUAV and EGC as independent variables 


$$
\mathrm{RC}_{\mathrm{it}}=\alpha_{0}+\beta_{1} \mathrm{EDUAV}_{\mathrm{it}}+\beta_{2} \mathrm{EGC}_{\mathrm{it}}+\beta_{3} \mathrm{GROWTH}_{\mathrm{it}}+\beta_{4} \mathrm{DA}_{\mathrm{it}}+\beta_{5} \mathrm{SIZE}_{\mathrm{it}}+\varepsilon_{\mathrm{it}}
$$

(2) model 1-2 using AS, CHIEF, and TECH as independent variables

$$
\mathrm{RC}_{i \mathrm{t}}=\alpha_{0}+\beta_{1} \mathrm{AS}_{\mathrm{it}}+\beta_{2} \mathrm{CHIEF}_{\mathrm{it}}+\beta_{3} \mathrm{TECH}_{\mathrm{it}}+\beta_{4} \mathrm{GROWTH}_{\mathrm{it}}+\beta_{5} \mathrm{DA}_{\mathrm{it}}+\beta_{6} \mathrm{SIZEA}_{\mathrm{it}}+\varepsilon_{\mathrm{it}}
$$

(3) model 1-3 using EDUAV, EGC, AS, CHIEF, TECH as independent variables

$$
\mathrm{RC}_{\mathrm{it}}=\alpha_{0}+\beta_{1} \mathrm{EDUAV}_{\mathrm{it}}+\beta_{2} \mathrm{EGC}_{\mathrm{it}}+\beta_{3} \mathrm{AS}_{\mathrm{it}}+\beta_{4} \mathrm{CHIEF}_{\mathrm{it}}+\beta_{5} \mathrm{TECH}_{\mathrm{it}}+\beta_{6} \mathrm{GROWTH}_{\mathrm{ir}}+\beta_{7} \mathrm{DA}_{\mathrm{it}}+\beta_{8} \mathrm{SIZE}_{\mathrm{it}}+\varepsilon_{\mathrm{it}}
$$

\subsubsection{Using Human Capital ROI (ROIHC) as Dependent Variable}

(1) model 2-1 using EDVUAV and EGC as independent variables

$$
\text { ROIHC }_{i t}=\alpha_{0}+\beta_{1} \text { EDUAV }_{i t}+\beta_{2} \text { EGC }_{i t}+\beta_{3} \text { GROWTH }_{i t}+\beta_{4} \text { DA }_{i t}+\beta_{5} \text { SIZE }_{i t}+\varepsilon_{i t}
$$

(2) model 2-2 using AS, CHIEF, and TECH as independent variables

$$
\mathrm{ROIHC}_{\text {it }}=\alpha_{0}+\beta_{1} \mathrm{AS}_{\mathrm{it}}+\beta_{2} \mathrm{CHIEF}_{i \mathrm{t}}+\beta_{3} \mathrm{TECH}_{\mathrm{it}}+\beta_{4} \mathrm{GROWTH}_{\mathrm{it}}+\beta_{5} \mathrm{DA}_{\mathrm{it}}+\beta_{6} \mathrm{SIZEA}_{\mathrm{it}}+\varepsilon_{i \mathrm{it}}
$$

(3) model 2-3 using EDUAV, EGC, AS, CHIEF, TECH as independent variables

$$
\mathrm{ROIHC}_{\text {it }}=\alpha_{0}+\beta_{1} \mathrm{EDUAV}_{\mathrm{it}}+\beta_{2} \mathrm{EGC}_{\text {it }}+\beta_{3} \mathrm{AS}_{\mathrm{it}}+\beta_{4} \mathrm{CHIEF}_{\mathrm{it}}+\beta_{5} \mathrm{TECH}_{\mathrm{it}}+\beta_{6} \mathrm{GROWTH}_{\mathrm{ir}}+\beta_{7} \mathrm{DA}_{\mathrm{it}}+\beta_{8} \mathrm{SIZE}_{\text {it }}+\varepsilon_{\text {it }}
$$

whereas,

RCit: Natural logarithm of the average revenue capacity; ROIHCit: the return on human capital investment; EDUAVit: Average number of years of education; EGCit: education Gini index; ASit: Natural logarithm of the average employees' compensation; CHIEFit: Natural logarithm of the average top managements' compensation; TECHit: ratio of skillful employees to total employees; GROWTHit: The growth rate of operating income; DAit: The asset-liability ratio; SIZEit: Natural logarithm of total assets; $i$ : the $i$ energy company; $t$ : year $t$; $\alpha_{0}$ : Constant coefficient; $\beta_{\mathrm{n}}: \mathrm{n}=1, \ldots, 8$, is the regression coefficient; Eit:
Random error value.

\section{Empirical Results}

\subsection{Correlation Analysis}

In this study, the correlation analysis between the independent variables and the control variables is shown in

\begin{tabular}{|c|c|c|c|c|c|c|c|c|}
\hline variable & EDUAV & EGC & AS & CHIEF & ТЕСН & GROWTH & DA & SIZE \\
\hline EDUAV & 1.000 & & & & & & & \\
\hline EGC & 0.147 & 1.000 & & & & & & \\
\hline AS & 0.525 & 0.166 & 1.000 & & & & & \\
\hline CHIEF & 0.162 & 0.303 & 0.381 & 1.000 & & & & \\
\hline TECH & 0.182 & 0.016 & 0.213 & 0.094 & 1.000 & & & \\
\hline GROWTH & -0.149 & -0.148 & -0.082 & -0.277 & -0.059 & 1.000 & & \\
\hline SIZE & 0.496 & 0.195 & 0.591 & 0.309 & 0.082 & -0.000 & 0.291 & 1.000 \\
\hline
\end{tabular}
Table 1. The correlation coefficient between the independent variable and all variables of the control variables is less than 0.7 , which shows that there is no collinearity between the above variables.

Table 1. Correlation analysis table.

\subsection{Hausman Test}

This study used the Hausman test to select a random effect model or a fixed effect model for OLS analysis. According to the Hausman test results, the probability of the number of cross-sectional objects is observed. If the probability is less than 0.1 , the fixed effect model should be selected; conversely, if the probability is greater than 0.1 , the random effect model should be selected. The Hausman test results in Table 2 show that the probabilities are all greater than 0.1 ; therefore, all models should be selected as random effects models.
Table 2. Hausman test results table.

\begin{tabular}{lll}
\hline & degrees of freedom & Prob. \\
\hline model1-1 & 5 & 0.100 \\
model1-2 & 6 & 0.284 \\
model1-3 & 8 & 0.257 \\
model2-1 & 5 & 0.607 \\
model2-2 & 6 & 0.180 \\
model2-3 & 8 & 0.361 \\
\hline
\end{tabular}

\subsection{Empirical Results}

According to the results of comprehensive empirical analysis, shown in table 3 the employee's education years and educational Gini index in the company's internal effects have a positive impact on business performance. On the other 
hand the average employees' compensation and average top managements' compensation in the company's in the company's external effects have a positive impact on business performance. In summary, human capital of Chinese listed energy companies plays an important role in business performance.

Table 3. Regression empirical results table.

\begin{tabular}{|c|c|c|c|c|c|c|}
\hline variable & Model1-1 & Model1-2 & Model1-3 & Model2-1 & Model2-2 & Model2-3 \\
\hline $\mathrm{C}$ & $2.950 * *[1.205]$ & $0.410[1.050]$ & $-1.562[1.083]$ & $-27.945^{* * *}[4.866]$ & $-25.153 * * *[5.727]$ & $-36.097 * * *[5.903]$ \\
\hline EDUAV & $0.309 * * *[0.057]$ & & $0.130 * * *[0.042]$ & $1.397 * * *[0.233]$ & & $1.320 * * *[0.240]$ \\
\hline EGC & $10.638 * * *[3.585]$ & & $7.717 * * *[2.618]$ & $-2.293[14.870]$ & & $-3.347[14.823]$ \\
\hline AS & & $0.857 * * *[0.061]$ & $0.784 * * *[0.062]$ & & $0.978 * * *[0.368]$ & $0.419[0.361]$ \\
\hline CHIEF & & $0.034[0.066]$ & $0.043[0.064]$ & & $0.341[0.394]$ & $0.599[0.372]$ \\
\hline TECH & & $0.052[0.232]$ & $0.090[0.226]$ & & $1.678[1.408]$ & $1.284[1.322]$ \\
\hline DA & $-0.335[0.296]$ & $0.125[0.216]$ & $0.209[0.222]$ & $-3.708 * * *[1.230]$ & $-5.038 * * *[1.242]$ & $-3.053 * *[1.248]$ \\
\hline SIZE & $0.263 * * *[0.044]$ & $0.132 * * *[0.036]$ & $0.143 * * *[0.036]$ & $0.540 * * *[0.183]$ & $0.615 * * *[0.193]$ & $0.393 * *[0.194]$ \\
\hline $\mathrm{R}^{2}$ & 0.343 & 0.607 & 0.646 & 0.314 & 0.228 & 0.340 \\
\hline Adj.- $\mathrm{R}^{2}$ & 0.325 & 0.594 & 0.631 & 0.296 & 0.203 & 0.311 \\
\hline F-stat & $19.374 * * *$ & $47.508 * * *$ & $41.659 * * *$ & $17.098 * * *$ & $9.140 * * *$ & $11.787 * * *$ \\
\hline
\end{tabular}

\section{Conclusion}

(1) The internal effect of human capital

China's listed energy companies should focus on employee's education years and the adjustment of human capital structure. Industry competition has gradually shifted from initial energy competition and asset competition to human capital competition. The company's focus is not only on physical assets, but also on the intangible assets. For new employees, we strictly control the recruitment of talents, attach importance to the education level of employees, and adjust the balance of human capital structure from the influx of talents. After introducing higheducated and high-educated talents, the company needs to optimize human capital management and rationally arrange human resources positions in order to maximize the economic benefits brought by the initial stock of human capital, so that people's strengths can be exerted and human values Reflected.

(2) The external effect of human capital

Chinese listed energy companies should pay attention to investment in human capital on the basis of the initial stock of human capital. Many companies are often committed to investing in external commercial economic activities to achieve economic returns, while ignoring the investment in the company's internal human capital, ignoring the potential of internal intangible capital development. In addition to the new inflows of employees, the company still has a large amount of historical capital of human resources. These historical capitals are usually experienced employees with rich experience and lack of academic qualifications. In the traditional energy industry, where personnel turnover is slow, these human capitals are still the main driving force for companies to create operational benefits.

According to this, enterprises should not only upgrade their employees' academic qualifications from new employees, but also focus on training and skills upgrading of existing human capital. This is also the inevitable choice for the company's internal human resources is approaching saturation, and the human capital structure needs to be optimized and upgraded. The company's investment in human capital is mainly reflected in two aspects: employee compensation and employee training funds. Within the scope of the company's business license, the promotion of employee compensation will give employees a great enthusiasm and motivation, and it is also an affirmation of the employee's work performance; the promotion of training funds can provide professional skilled personnel to fully exploit the potential of the company's internal human capital. To provide a continuous and sustainable driving force for the improvement of the status quo of the human capital structure of enterprises and the reform and transformation of the business development model.

\section{Acknowledgements}

This paper was supported by Philosophy and Social Science planning funded project of Zhanjiang City (Grant Number: ZJ19QN03).

\section{References}

[1] Becker, G. S. (1993). The economic way of looking at behavior: The Nobel Lecture. Journal of Political Economy, (101): 385-409.

[2] Becker, G. S. (1964). Human capital: A theoretical and empirical analysis with special reference to education. New York: Columbia University Press.

[3] Coleman, J. S. (1998). Social capital in the creation of human capital. American Journal of Sociology, (94): 95-120.

[4] Schultz, T. W. (1961). Investment in human capital. The American Economic Review, 51 (1), 1-17.

[5] Brooking, A. (1996). Intellectual capital: Core asset for third millennium enterprise. London: International Thomson Business Press. 
[6] Pennings, J. M., Lee, K., and Witteloostuijn, A. (1998). Human capital, social capital and firm dissolution. The Academy of Management Journal, 41 (4): 425-440.

[7] Namasivayam, K. and Denizci, B. (2006). Human capital in service organizations: Identifying value drivers. Journal of Intellectual Capital, 7 (3): 381-393.

[8] Dzinkowski, R. (2000). The measurement and management of intellectual capital: An introduction. Financial Management, 78 (2): $32-36$

[9] Becker, B. E., Husield, M. A., and Ulrich, D. (2001). The HR scorecard: Linking people, strategy, and performance. Boston: Harvard Business School Press.

[10] Hillman, A. J. and Dalziel, T. (2003). Boards of directors and firm performance: Integrating agency and resource dependence perspectives. The Academy of Management Review, 28 (3): 383-396.
[11] Teixeira, A. A. C. and Queiros A. S. S. (2015). Economic growth, human capital and structural change: A dynamic panel data analysis. Research Policy, 45 (8), 1636-1648.

[12] Maas, J. V. L. and Criel, G. (1982). Distribution of primary school enrollments in Eastern Africa [J]. World Bank Staff Working Papers Number 511.

[13] Ballot, G., Fakhfakh F. and Taymaz, E. (2001). Firms' human capital, R\&D and performance: A study on French and Swedish firms. Labour Economics, 8 (4): 443-462.

[14] Peng, Y., Suying, G., Long, X. (2017). The influence of human capital and employee human capital on firm performance: An analysis of the mediating effect of adjustment. Journal of Technology Economics and Management, (4): 52-58.

[15] Fedyk, A. and Hodson, J. (2017). Trading on talent: Human capital and firm performance. Working paper. 